\title{
Cerebral Metabolism of Imipramine and a Purified Flavin-Containing Monooxygenase from Human Brain
}

Shripad V. Bhagwat, M.Sc., Shubhada Bhamre, Ph.D., Michael R. Boyd, M.D., Ph.D., and Vijayalakshmi Ravindranath, Ph.D.

Flavin-containing monooxygenase (FMO), previously reported both from hepatic and extrahepatic tissues, including brain, catalyze the oxidation of certain xenobiotics and drugs that contain a nucleophilic heteroatom. Psychoactive drugs, including the antidepressant imipramine, are substrates for the brain FMO. Since FMO-mediated metabolism of these drugs might contribute to local pharmacodynamic modulation within the human brain, the metabolism of imipramine by human brain FMO was studied in further detail. In the present study, the FMO activity was determined in human brain microsomes by estimating the actual amount of imipramine $N$-oxide formed. It was then compared with the corresponding activity measured using substrate (imipramine)-stimulated rates of nicotinamide adenine dinucleotide phosphate (NADPH) oxidation, which was significantly higher than the activity estimated as the amount of $N$-oxide assayed using high-pressure liquid chromatography (HPLC). The brain FMO activity was measurable only in the presence of detergents (sodium cholate or Lubrol PX) or in microsomes that were freeze-thawed several times. The activity was inhibited by an antibody to rabbit pulmonary FMO, but an antiserum to the rat liver NADPH cytochrome P-450 reductase had no effect indicating that cytochrome P-450 was not involved in the above metabolic pathway. The optimum $\mathrm{pH}$ for $\mathrm{N}$-oxidation of imipramine was found to be 8.5; thermolability experiments indicated that the FMO activity was completely lost only after the incubation of brain microsomes at $45^{\circ} \mathrm{C}$ for 20 minutes. An FMO purified to apparent homogeneity from a human brain had a molecular weight of 71,000 Da. The purified enzyme cross-reacted with the antibody to rabbit pulmonary FMO and efficiently catalyzed the metabolism of imipramine to its $\mathrm{N}$-oxide. The human brain clearly contains an active FMO system, and it is conceivable that such enzymes are significantly involved in the local metabolism and modulation of pharmacological and/or toxic effects of certain xenobiotics, including psychoactive drugs. [Neuropsychopharmacology 15:133-142, 1996]
KEY WORDS: Drug metabolism; Psychoactive drugs; Brain; Flavin-containing monooxygenase (FMO); Human subjects

From the Department of Neurochemistry (SVB, SB, VR), National Institute of Mental Health and Neurosciences, Bangalore, India; and the Laboratory of Drug Discovery, Research, and Development (MRB), Development Therapeutics Program, National Cancer Institute, National Institutes of Health, Frederick, MD.

Address correspondence to: $\mathrm{V}$. Ravindranath, Department of Neurochemistry, NIMHANS, Hosur Road, Bangalore, 560029, India.

Received May 31, 1995; revised August 9, 1995; accepted September 7, 1995 .
Microsomal flavin-containing monooxygenases (FMO) catalyze the nicotinamide adenine dinucleotide phosphate (NADPH)-dependent oxidation of a variety xenobiotics that contain nucleophilic heteroatoms. Typically, nitrogen-, sulfur-, or phosphorus-containing functional groups are sites for oxidation by the enzyme (Ziegler 1993). Many psychoactive drugs fall into this category and are substrates for hepatic and extrahepatic FMOs in several species of laboratory animals. The presence of FMO activity has been documented in various organs, including the liver (Poulsen et al. 1974), lung (Williams 
et al. 1985), and kidney (Bhamre et al. 1993a). Hepatic and pulmonary FMO have been purified from a variety of experimental animals and appear to be distinct proteins (Ziegler and Poulsen 1978; Williams et al. 1985; Tynes and Philpot 1987).

FMO-mediated oxidation of $\mathrm{N}^{\prime}, \mathrm{N}^{\prime}$-dimethylaniline has been demonstrated in adult and fetal human liver (Gold and Ziegler 1973). More recently, FMO-mediated metabolism of imipramine has been reported in human kidney (Lemoine et al. 1990). Human hepatic FMO has been cloned and sequenced (Dolphin et al. 1991; Lomri et al. 1992). Generally, little information is available on the human FMO compared to that on the other major drug-metabolizing enzyme family, the cytochromes P-450.

The FMO-mediated metabolism of antidepressants such as imipramine, amitriptyline, or nortriptyline leads to the formation of their respective $\mathrm{N}$-oxides, which are pharmacologically inactive. Earlier studies from our laboratory have demonstrated the presence of FMO in the rat brain and the enzyme's ability to metabolize model substrates (Bhamre and Ravindranath 1991) and antidepressants, such as imipramine and fluoxetine (Bhamre et al. 1993b).

The capability of the human brain to carry out FMOmediated metabolism of model substrates and psychoactive drugs (such as imipramine, fluoxetine, and chlorpromazine) has been examined in autopsy brain specimens obtained from traffic accident victims (Bhamre et al. 1995). These studies have revealed the presence of a competent FMO system in the human brain, capable of metabolizing imipramine, fluoxetine, and chlorpromazine with high affinity and high activity. The metabolism of these drugs was measured in various regions of human brain. The FMO activity did not show significant variation among the different regions of the brain that were examined. The brain FMO shares immunological similarity with the rabbit pulmonary FMO; immunocytochemistry using the above antibody has revealed the preferential localization of the brain FMO in the neuronal cells. The presence of a functional FMO system in the brain would potentially have far-reaching pharmacodynamic implications in psychoactive drug therapy. If metabolism were to take place at the site of action of the drugs, these metabolic pathways might significantly mediate pharmacodynamic effects.

Here we report investigations on the human brain FMO-mediated N-oxidation of imipramine, measuring by high-pressure liquid chromatography (HPLC) the actual amount of the metabolite (imipramine $\mathrm{N}$-oxide) formed and comparing it with the activity obtained using the traditional method of assessment of FMO activity, namely, the measurement of substrate-stimulated rate of NADPH oxidation. The effects of detergents, $\mathrm{pH}$, and temperature also have been assessed. As an essential part of these investigations, a human brain FMO was purified to apparent homogeneity from the cortical microsomes prepared from a human brain obtained at autopsy.

\section{MATERIALS AND METHODS}

\section{Human Brain Tissue}

Human brain tissues were obtained at autopsy from traffic accident victims. None of the subjects had any known neurological disorders. Two of the three victims were aged 60 and 50 years, respectively (Case 1 and Case 2). The interval between death and autopsy was 8 and 12 hours, respectively. Human brain tissue used for the purification of FMO was obtained from a male traffic accident victim, aged 43 years (Case 3 ). The interval between death and autopsy was 10 hours. Grossly, the brains were normal with no evidence of trauma, atrophy, or other anomalies. Following autopsy, the meninges and blood vessels were removed, and the whole cortex was dissected out using appropriate anatomical landmarks. The tissues were stored at $-70^{\circ} \mathrm{C}$ prior to analysis.

\section{Preparation of Microsomes}

Microsomes were prepared by a calcium aggregation method as described (Ravindranath and Anandatheerthavarada 1990; Bhamre et al. 1993b). Microsomal protein concentrations were estimated by a dye-binding method (Bradford 1976) and by the method of Lowry (Lowry et al. 1951).

Assay of Imipramine N-Oxidation by Measurement of NADPH Oxidation Rate. FMO activity was assayed by measuring the substrate-stimulated rate of NADPH oxidation using imipramine as substrate. The assay buffer consisted of $0.1 \mathrm{M}$ tris- $\mathrm{HCl}(\mathrm{pH} 8.4)$ containing EDTA (1 mM), $n$-octylamine ( $3 \mathrm{mM})$, and Triton $\mathrm{N}-101$ $(0.1 \%, v / v)$ and was bubbled with oxygen prior to use. The microsomal protein concentration was 10 to $30 \mu \mathrm{g} /$ $\mathrm{ml}$ incubation. The assay was carried out essentially as described in Bhamre et al. (1993b). The brain microsomes were incubated with NADPH, and the endogenous rate of NADPH oxidation was monitored at 340 $\mathrm{nm}$ for 3 to 5 minutes until the endogenous rate of NADPH oxidation was negligible, as evidenced by the absence of measurable change in absorbance at $340 \mathrm{~nm}$. The substrate, imipramine, was added thereafter, and the substrate-stimulated rate of NADPH oxidation was monitored. The endogenous rate was typically 10 to 16 nmoles of NADPH oxidized $/ \mathrm{min} / \mathrm{mg}$ protein. The minimal detectable activity was 8 to 10 nmoles of $\mathrm{NADPH}$ oxidized $/ \mathrm{min} / \mathrm{mg}$ protein.

Measurement of FMO Activity by Estimation of Imipramine $\mathrm{N}$-Oxide Formation by HPLC. Imipramine $\mathrm{N}$-oxidation by human brain microsomes was also de- 
termined by HPLC. The incubation mixture $(1 \mathrm{ml})$ consisted of $0.2 \mathrm{M}$ tris- $\mathrm{HCl}(\mathrm{pH} 8.5)$, containing $1 \mathrm{mM}$ EDTA, $n$-octylamine ( $3 \mathrm{mM}$, an inhibitor of cytochrome $\mathrm{P}-450)$, sodium cholate $(0.6 \%, \mathrm{w} / \mathrm{v}$, unless otherwise stated), 5 to $40 \mu \mathrm{g}$ of microsomal protein, and $1 \mathrm{mM}$ NADPH. After preincubation for 3 minutes, imipramine was added at a final concentration of $10 \mu \mathrm{M}$, unless indicated otherwise. After incubation at $37^{\circ} \mathrm{C}$ for varying periods (0.5-2 minute), $0.1 \mathrm{ml}$ of methanol (containing a trace of orthophosphoric acid to bring the $\mathrm{pH}$ of the mixture to 5) was added to stop the reaction. The reaction mixture was mixed and centrifuged at $5,000 \mathrm{rpm}$ for 10 minutes. The supernatant was filtered through a $0.22-\mu \mathrm{m}$ Nylon membrane and subjected to HPLC analyses. Blank incubations were carried out simultaneously without the addition of NADPH or using boiled microsomes. Imipramine $\mathrm{N}$-oxide was not detectable in blank incubations. The minimal detectable limit of imipramine $\mathrm{N}$-oxide by HPLC was 8 nmoles of $\mathrm{N}$-oxide formed $/ \mathrm{min} / \mathrm{mg}$ protein. The HPLC analysis was carried out using a Supelco LC-CN column $(15 \mathrm{~cm} \times$ $4.6 \mathrm{~mm}, 5 \mu \mathrm{m})$. The mobile phase for HPLC consisted of acetonitrile:methanol:potassium phosphate buffer $(0.01 \mathrm{M}, \mathrm{pH} 4.8)$ in the ratio of 20:15:65 (v/v). Metabolite detection was performed using an ultraviolet detector set at $251 \mathrm{~nm}$. Data acquisition from the HPLC output and peak integration were delayed by 5 minutes following the injection of samples. Varying concentrations of standard imipramine $\mathrm{N}$-oxide were also subjected to HPLC analyses, and a standard curve was drawn using peak areas. The concentration of the N-oxide formed in the microsomal incubation was calculated from the standard curve.

\section{Effect of Detergents}

The effect of the addition of detergents, Lubrol PX $(0.1 \%, v / v)$ or sodium cholate $(0.6 \%, w / v)$, on FMOmediated metabolism of imipramine by rat brain microsomes was determined by adding any one of these detergents at a time to the assay buffer. The activity was also measured in the absence of detergents using microsomes that were freeze-thawed several times.

\section{Effect of $\mathbf{p H}$}

The buffer used for the activity measurements contained $0.2 \mathrm{M}$ tris and $1 \mathrm{mM}$ EDTA. The $\mathrm{pH}$ of the buffer was adjusted variably from 6.5 to 10 with $\mathrm{HCl}$ to study the effect of $\mathrm{pH}$ on brain FMO activity. The assay buffer also contained Triton N-101 (0.1\%, v/v) and $n$-octylamine ( $3 \mathrm{mM})$. NADPH was added at a final concentration of $0.1 \mathrm{mM}$. FMO activity was measured using the assay buffers of varying $\mathrm{pH}(\mathrm{pH} 6.5$ to 10 ) by following the substrate-stimulated rate of NADPH oxidation at $340 \mathrm{~nm}$ and using imipramine as a substrate.

\section{Thermolability Experiments}

Microsomes were incubated at $45^{\circ} \mathrm{C}$ for 5 minutes, 10 minutes, 15 minutes, or 20 minutes and then used for assay of FMO activity by measuring the substrate-stimulated rate of NADPH oxidation.

\section{Competitive Inhibition Studies}

Methimazole ( $3 \mathrm{mM})$ was added as a competitive substrate alone with imipramine, after the preincubation of the microsomes with NADPH as detailed above.

\section{Immunoinhibition Studies}

Human brain microsomes $(20 \mu \mathrm{g})$ were preincubated with antibody to rabbit pulmonary FMO $(20 \mu \mathrm{l})$ or antiserum to rat liver NADPH cytochrome P450 reductase $(20 \mu \mathrm{l})$ for 30 minutes at $4^{\circ} \mathrm{C}$ prior to the initiation of the assay. Microsomes preincubated with nonimmune sera served as controls.

\section{Purification of Human Brain FMO}

The microsomes were prepared from the human brain cortex as described. All buffers used for purification contained EDTA (1 mM), phenylmethylsulfonyl fluoride $(0.1 \mathrm{mM})$, butylated hydroxytoluene $(22 \mu \mathrm{M})$, and dithiothreitol $(0.1 \mathrm{mM})$ and were bubbled with nitrogen prior to use. All procedures were carried out at $4^{\circ} \mathrm{C}$. During the purification, FMO activity was monitored by measuring the substrate-stimulated rate of NADPH oxidation using imipramine as substrate (Bhamre et al. 1993b).

Microsomes were suspended to a final concentration of $2 \mathrm{mg} / \mathrm{ml}$ in phosphate buffer $(0.1 \mathrm{M}, \mathrm{pH} 7.4)$ containing $30 \%$ glycerol $(\mathrm{v} / \mathrm{v})$; sodium cholate was added dropwise to a final concentration of $0.6 \%(\mathrm{w} / \mathrm{v})$. After stirring for an additional 30 minutes, the solution was centrifuged at $100,000 \mathrm{~g}$ for 1 hour, and the supernatant was loaded onto an $n$-octylamino Sepharose $4 \mathrm{~B}$ column that had been previously equilibrated with phosphate buffer $(0.1 \mathrm{M}, \mathrm{pH} 7.25)$ containing $20 \%$ glycerol and $0.6 \%$ cholate. The column was washed with the equilibration buffer, and the FMO-containing fractions were eluted by the same buffer. The fractions containing FMO activity (estimated using imipramine as substrate) were pooled, concentrated and, dialyzed overnight against $20 \%$ glycerol. The partially purified protein was applied to a $2^{\prime}, 5^{\prime}$-ADP agarose column that had been previously equilibrated with potassium phosphate buffer $(0.01 \mathrm{M}, \mathrm{pH} 7.7)$ containing $20 \%$ glycerol and $0.42 \%$ sodium cholate. The column was washed with the buffer, and FMO was eluted using a linear gradient of 0 to $0.25 \mathrm{mM}$ NADPH contained in the equilibration buffer. The fractions containing FMO activity were 
Table 1. Effect of Detergents on Human Brain FMO-Mediated Oxidation of Imipramine

\begin{tabular}{lcc}
\hline & \multicolumn{2}{c}{ Human Brain FMO Activity } \\
\cline { 2 - 3 } & Method A & Method B \\
\hline $\begin{array}{l}\text { 1. - detergent } \\
\text { 2. + sodium cholate }(0.6 \% \mathrm{w} / \mathrm{v})\end{array}$ & $\mathrm{ND}^{a}$ & $\mathrm{ND}$ \\
3. + Lubrol PX $(0.1 \% \mathrm{v} / \mathrm{v})$ & 124.5 & 85.5 \\
4. Freeze-thawed microsomes & 108.5 & 60.4 \\
$\quad \quad(5$ times) & 72.3 & 42.6 \\
5. Freeze-thawed microsomes & & 64.3 \\
$\quad(8$ times) & 93.2 & 59.0 \\
6. + detergent (assay buffer not & 76.4 & (Sodium cholate) \\
\hline
\end{tabular}

"ND indicates that the activity was below detection limit.

pooled, concentrated, and dialyzed against potassium phosphate buffer $(0.01 \mathrm{M}, \mathrm{pH} 7.7)$ containing $20 \%$ glycerol and $0.2 \%$ sodium cholate. The dialyzed concentrate was then loaded on to a DEAE-Sephacel column that was equilibrated with potassium phosphate buffer $(0.01$ $\mathrm{M}, \mathrm{pH} 7.7$ ) containing $20 \%$ glycerol and $0.2 \%$ sodium cholate. The column was washed with equilibration buffer, and the FMO was eluted in the buffer containing $500 \mathrm{mM} \mathrm{NaCl}$. The fractions containing FMO were pooled, concentrated, and dialyzed against potassium phosphate buffer $(0.01 \mathrm{mM}, \mathrm{pH} 7.7)$ containing $20 \%$ glycerol. During purification, the FMO activity was measured using imipramine as a substrate. The substrate-stimulated rate of NADPH oxidation was monitored.

Purified FMO was subjected to sodium dodecylsulfate polyacrylamide gel electrophoresis (SDS-PAGE, Laemmli 1970) and the gel was silver stained (Merril et al. 1981). Following SDS-PAGE, the purified FMO was also transferred on to nitrocellulose membrane (Towbin et al. 1979) and immunostained using antibody to rabbit pulmonary FMO (Williams et al. 1985).

\section{RESULTS}

FMO activity was not detectable in freshly thawed brain microsomes in the absence of detergents using either of the two methods (Table 1).

Microsomal protein $(5-10 \mu \mathrm{g})$ was incubated in $0.2 \mathrm{M}$ tris buffer ( $\mathrm{pH} 8.5$ ) containing $1 \mathrm{mM}$ EDTA, $0.1 \mathrm{mM}$ NADPH, $3 \mathrm{mM} n$-octylamine, imipramine $(10 \mu \mathrm{M})$, and the detergents as indicated. The activity was assayed either by measuring the NADPH-utilizing rates (Method A) or by estimating the amount of imipramine $\mathrm{N}$-oxide formed by HPLC (Method B). The activities are expressed as nmoles of NADPH oxidized $/ \mathrm{min} / \mathrm{mg}$ protein (Method $\mathrm{A}$ ) or nmoles of imipramine $\mathrm{N}$-oxide formed $/ \mathrm{min} / \mathrm{mg}$ protein (Method B). In experiments performed with assay buffer that had not been previ- ously bubbled with oxygen, the detergent added for the assay of FMO activity is given in parenthesis. Values are an average of four determinations (which did not differ by more than $10 \%$ ) using human brain microsomes from Case 1 (see Methods).

The activity was measurable only after the addition of detergents (sodium cholate or Lubrol PX) to the assay buffer. The formation of imipramine $\mathrm{N}$-oxide could not be measured when Triton N-101 was added to the assay buffer, because this detergent interfered with the HPLC analysis. The FMO activity determined in the presence of Lubrol PX using the HPLC method (Figure 1) was 60.4 nmoles of imipramine N-oxide formed $/ \mathrm{min} / \mathrm{mg}$ protein, which was similar to that observed in freezethawed ( 8 times) microsomes incubated in the absence of detergents (64.3 nmoles of imipramine $\mathrm{N}$-oxide formed $/ \mathrm{min} / \mathrm{mg}$ protein). The FMO activities estimated as substrate-stimulated rates of NADPH oxidation were 108.5 and 93.2 nmoles of NADPH oxidized/ $\mathrm{min} / \mathrm{mg}$ protein in microsomes incubated in presence of nonionic detergents (such as Lubrol PX) and in freeze-thawed microsomes, respectively. Maximal activity was, however, observed in microsomes incubated with sodium cholate (124.5 nmoles of NADPH oxi$\mathrm{dized} / \mathrm{min} / \mathrm{mg}$ protein or 85.5 nmoles of imipramine $\mathrm{N}$-oxide formed $/ \mathrm{min} / \mathrm{mg}$ protein), which was substantially higher than that observed in the presence of the other detergent (Table 1). In general, the FMO activity measured as NADPH utilization rates was higher than the FMO activity measured by HPLC as the amount of $\mathrm{N}$-oxide formed; that is, only $56 \%$ to $69 \%$ of the activity measured as NADPH utilization rate. The enzyme activity was also estimated in detergent (sodium cholate or Triton N-101, respectively) containing buffer that was not bubbled with oxygen; in this case the activities were determined to be 59 nmoles of imipramine $\mathrm{N}$-oxide formed $/ \mathrm{min} / \mathrm{mg}$ protein and 76.4 nmoles of NADPH oxidized $/ \mathrm{min} / \mathrm{mg}$ protein (Table 1 ).

The brain FMO-mediated metabolism of imipramine was estimated by measuring the substrate-stimulated 


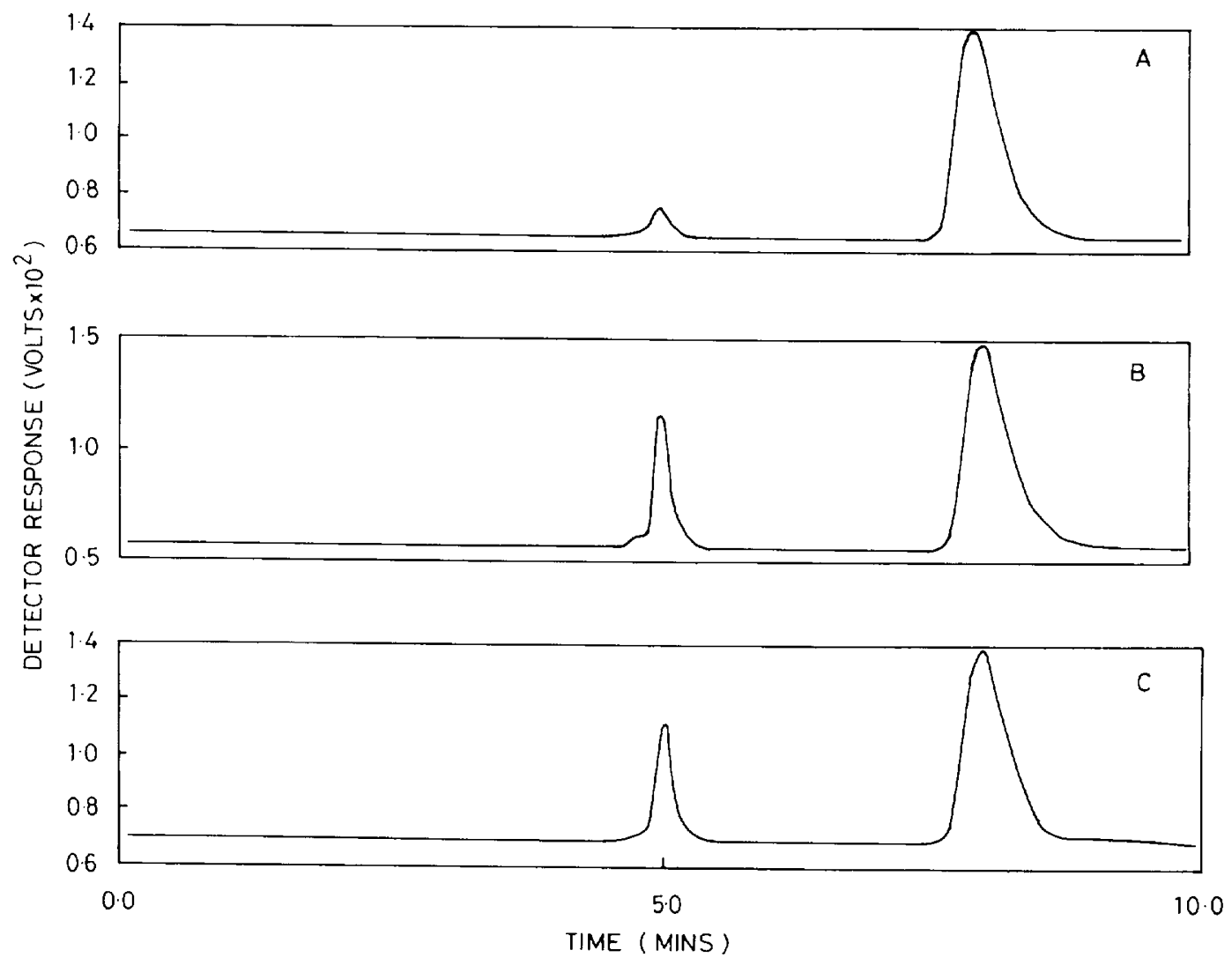

Figure 1. HPLC elution profiles of (A) incubation performed with freshly thawed microsomes in the absence of detergents; (B) incubation performed with freeze-thawed (8 times) microsomes in the absence of detergents; and (C) incubations carried out with freshly thawed microsomes in the presence of sodium cholate $(0.6 \%, \mathrm{~W} / \mathrm{v})$. Human brain cortical microsomes $(20$ $\mu \mathrm{g}$, from Case 1) were incubated in tris buffer $(0.2 \mathrm{M}, \mathrm{pH} 8.5)$ containing EDTA (1 mM), $n$-octylamine (3 mM), and NADPH $(1 \mathrm{mM})$ at $37^{\circ} \mathrm{C}$ for 1 minute and then subjected to HPLC analyses as described under Methods. The first peak is imipramine $\mathrm{N}$-oxide, and the second peak represents unchanged imipramine.
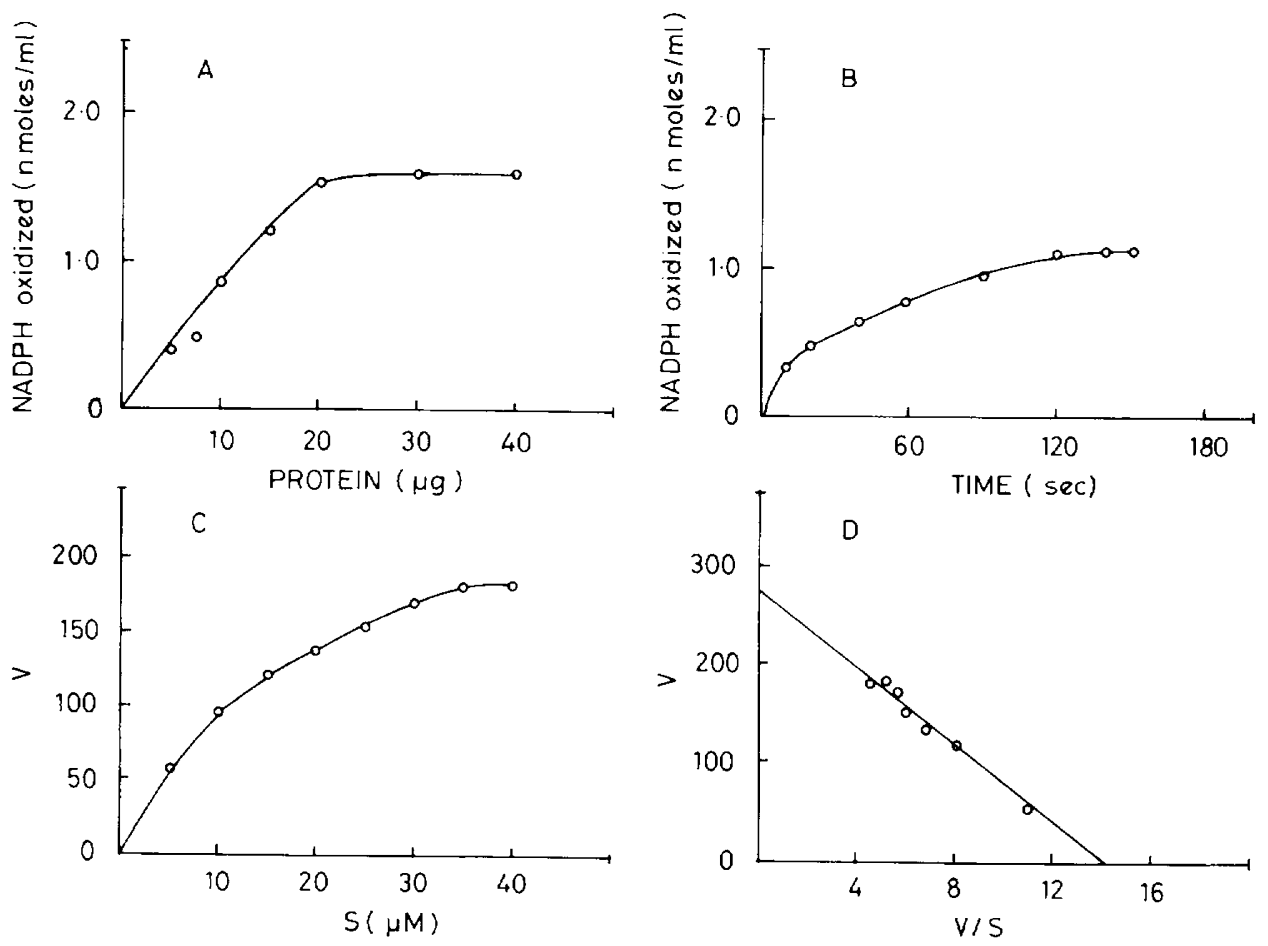

Figure 2. Effects of (A) microsomal protein concentration; (B) incubation time; and $(C, D)$ substrate concentration on human brain FMOmediated $\mathrm{N}$-oxidation of imipramine (measured as NADPH oxidation rates). (A) Microsomal protein (from Case 1) was incubated for 1 minute with $10 \mu \mathrm{M}$ imipramine. (B) Microsomal protein $(10 \mu \mathrm{g})$ was incubated with imipramine $(10 \mu \mathrm{M})$ for varying periods of time. (C) Microsomal incubations were performed with varying substrate concentrations (S) for 1 minute; the protein concentration was $10 \mu \mathrm{g}$. (D) The Eadie-Hoftsee plot of the data from $\mathbf{C}$. 

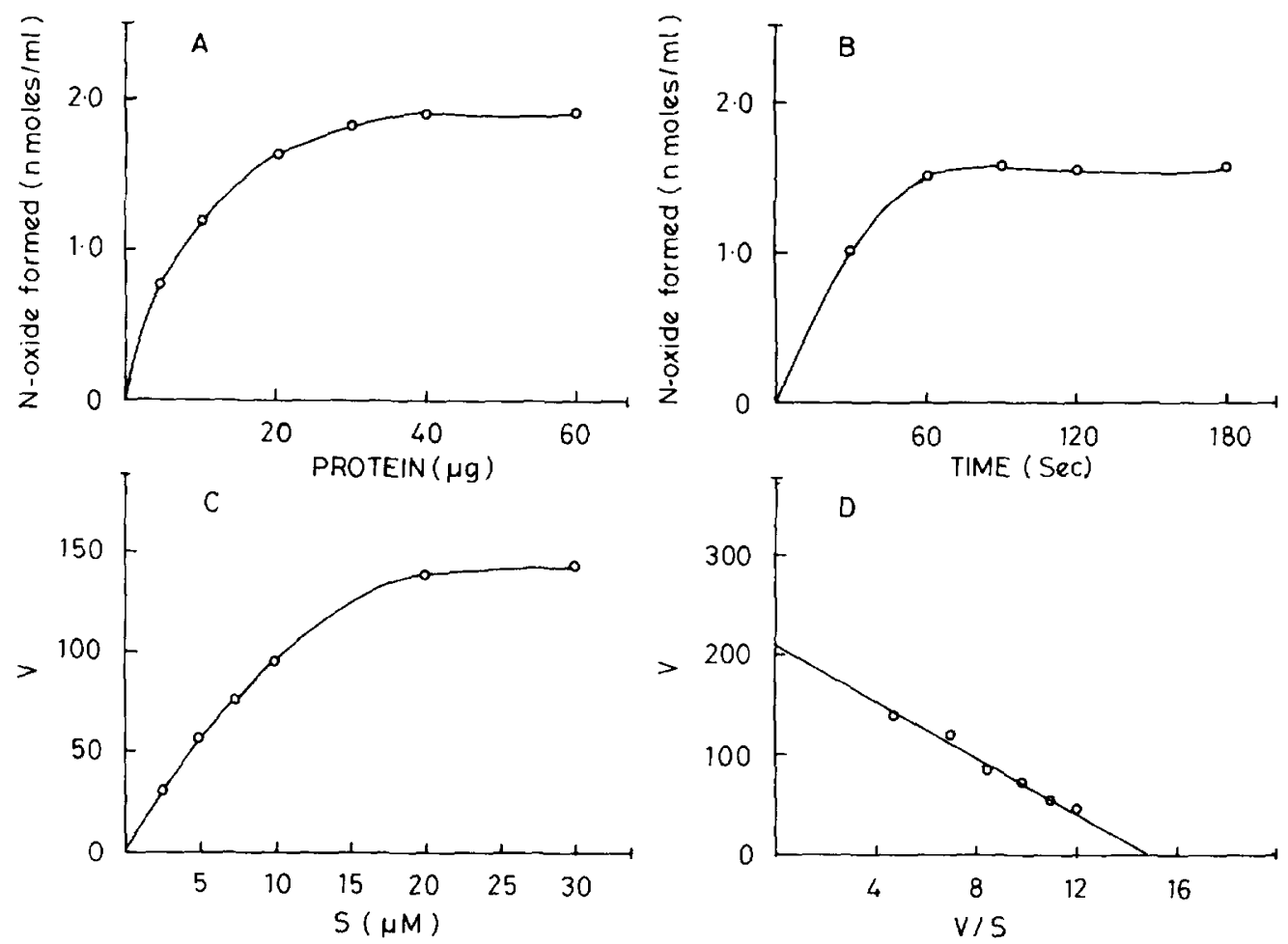

Figure 3. Effects of (A) microsomal protein concentration; (B) incubation time; and (C, D) substrate concentration on human brain FMO-mediated N-oxidation of imipramine (measured as the amount of imipramine $\mathrm{N}$-oxide formed). (A) Microsomal protein (from case 1) was incubated for 1 minute with $10 \mu \mathrm{M}$ imipramine. (B) Microsomal protein (10 $\mu$ g) was incubated with imipramine $(10 \mu \mathrm{M})$ for varying periods of time. (C) Microsomal incubations were performed with varying substrate concentrations (S) for 1 minute; the protein concentration was $10 \mu \mathrm{g}$. (D) The Eadie-Hoftsee plot of the data from C.

rates of NADPH oxidation (Figure 2). The enzyme activity increased linearly over a protein concentration of 5 to $20 \mu \mathrm{g}$ of protein and up to an incubation time of 120 seconds ( 2 minutes). The apparent $K_{\mathrm{m}}$ and $V_{\max }$ were determined to be $17.7 \mu \mathrm{M}$ and 265 nmoles of NADPH oxidized $/ \mathrm{min} / \mathrm{mg}$ protein, respectively. In contrast, when the FMO activity was measured by estimating the actual amount of product (imipramine $\mathrm{N}$-oxide) formed using HPLC (Figure 3 ), the apparent $K_{\mathrm{m}}$ and $V_{\max }$ were determined to be $14 \mu \mathrm{M}$ and 210 nmoles of imipramine $\mathrm{N}$-oxide formed $/ \mathrm{min} / \mathrm{mg}$ protein, respectively.

Preincubation of human brain microsomes with antibody to rabbit pulmonary FMO resulted in almost complete $(93 \%)$ inhibition of the FMO-mediated metabolism of imipramine to the N-oxide; HPLC analysis revealed the formation of only minute amounts of the $\mathrm{N}$-oxide. However, the $\mathrm{N}$-oxide was detectable in substantial quantity in the microsomal incubations performed with nonimmune IgG (Table 2).

Microsomal protein $(10 \mu \mathrm{g})$ in $0.2 \mathrm{M}$ tris buffer $(\mathrm{pH}$ 8.5) containing $1 \mathrm{mM}$ EDTA, $0.1 \mathrm{mM}$ NADPH, $3 \mathrm{mM}$ $n$-octylamine, sodium cholate $(0.6 \% \mathrm{w} / \mathrm{v})$, and imipramine $(10 \mu \mathrm{M})$ was preincubated with immune or nonimmune antibody for 30 minutes at $4^{\circ} \mathrm{C}$. In some experiments methimazole $(3 \mathrm{mM})$ was added along with imipramine. The activity was then assayed either by measuring the NADPH-utilizing rates (Method A) or by estimating the amount of imipramine $\mathrm{N}$-oxide formed by HPLC (Method B). The activities are expressed as nmoles of NADPH oxidized $/ \mathrm{min} / \mathrm{mg}$ protein (Method A) or nmoles of imipramine $\mathrm{N}$-oxide formed $/ \mathrm{min} / \mathrm{mg}$ protein (Method B). Values are mean of quadruplicate estimations (which did not differ by more than $10 \%$ ) using human brain microsomes from Case 1 (see Methods).

FMO activity was inhibited by only $32 \%$ by the above antibody, when the activity was measured by NADPH oxidation rates (Table 2). This antibody was selective in inhibiting imipramine $\mathrm{N}$-oxidation; FMO-mediated oxidation of fluoxetine was unaffected (data not shown). The antiserum to rat hepatic NADPH cytochrome P-450 reductase $(20 \mu \mathrm{l})$ had no effect on the FMO activity, measured using either method, indicating that there was no involvement of cytochrome P-450 in the biotransformation pathway. Earlier experiments have shown that $10 \mu \mathrm{l}$ of this antiserum completely inhibits NADPH cytochrome $c$ reductase activity in brain microsomes (Ravindranath and Anandatheerthavarada 1990). The addition of a competitive substrate to FMO, such as methimazole $(3 \mathrm{mM})$, resulted in the inhibition of FMO activity by $85 \%$ and $72 \%$, respectively, as mea- 
Table 2. Inhibition of Human Brain FMO-Mediated N-Oxidation of Imipramine

\begin{tabular}{lcr} 
& \multicolumn{2}{c}{ Human Brain FMO Activity } \\
\cline { 2 - 3 } & Method A & Method B \\
\hline 1. + Nonimmune goat IgG & 95.0 & 84.8 \\
2. + Antibody to rabbit pulmonary FMO & 64.3 & 6.0 \\
3. + Nonimmune rabbit serum & 112.5 & 83.5 \\
4. + Antiserum to rat hepatic NADPH & & 78.4 \\
$\quad$ cytochrome P450 reductase & 110.5 & 12.8 \\
5. + Methimazole (3 mM) & 26.8 & \\
\hline
\end{tabular}

sured using the HPLC method or by NADPH oxidation rates (Table 2 ).

Brain FMO-mediated metabolism of imipramine was maximal when the $\mathrm{pH}$ of the assay buffer was 8.5 . The activity declined below or above this $\mathrm{pH}$ (Figure 4). Preincubation of microsomes at $45^{\circ} \mathrm{C}$ for 10 minutes resulted in the loss of $50 \%$ of the FMO activity; no activity was detectable when the microsomes were incubated at $45^{\circ} \mathrm{C}$ for 20 minutes (Figure 5).

A human brain FMO was purified to apparent homogeneity from the cortical microsomes. The specific activities of the various fractions during the purification process are given in Table 3. Imipramine was used as the substrate for determining FMO activity. The yield of the purified $\mathrm{FMO}$ was $0.05 \%$, and the specific activity was $1,769 \mathrm{nmoles}$ of NADPH oxidized $/ \mathrm{min} / \mathrm{mg}$ protein. The metabolism of imipramine to its $\mathrm{N}$-oxide by the purified human brain FMO was monitored by HPLC. Incubation of purified human brain FMO with imipramine in the presence of NADPH resulted in the formation of imipramine $\mathrm{N}$-oxide. In the absence of $\mathrm{NADPH}$, the N-oxide was not formed (data not shown). The purified protein migrated as a single band on sodium dodecylsulfate-polyacrylamide gel electrophoresis; the molecular weight was determined to be 71,000 $\mathrm{Da}$ (Figure 6A). Immunoblot analysis using the antibody to purified rabbit pulmonary FMO revealed the presence of a single immunoreactive protein, indicating that the purified human brain FMO shared immunological similarity with the rabbit pulmonary FMO (Figure 6B).

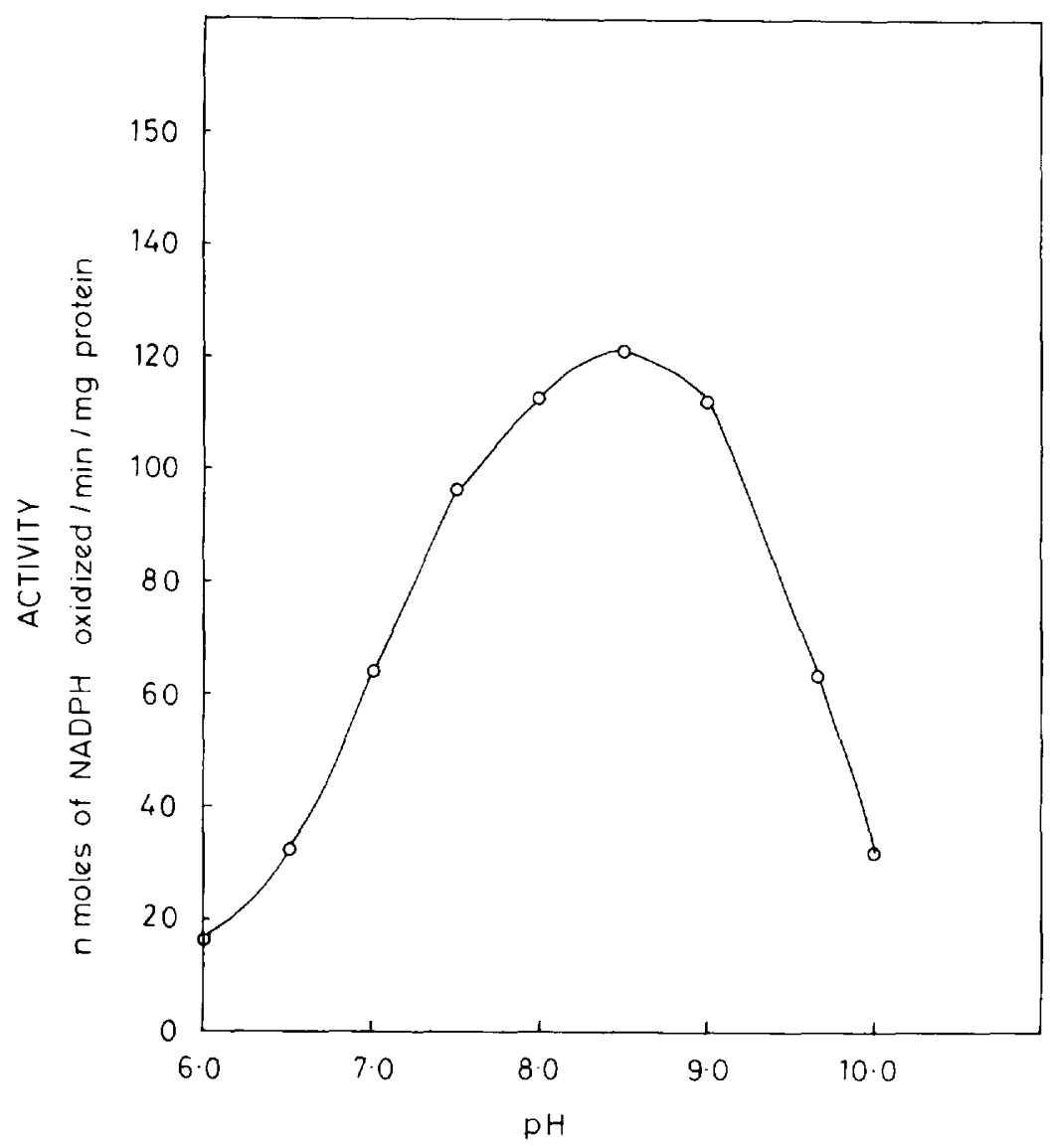

Figure 4. The effect of $\mathrm{pH}$ on brain FMOmediated oxidation of imipramine. Human brain microsomes (from Case 2, 10-20 $\mu \mathrm{g}$ ) were suspended in assay buffer of varying $\mathrm{pH}$ (6.5 to 10$)$, and the substrate-stimulated rate of NADPH oxidation $(10 \mu \mathrm{M}$ imipramine) was measured as described in Methods. Values are averages of triplicate measurements. 
Figure 5. The effect of temperature on brain FMO-mediated oxidation of imipramine. Brain microsomes (from Case 2, 10-20 $\mu \mathrm{g}$ ) were suspended in the assay buffer ( $\mathrm{pH} 8.5$ ) and heated at $45^{\circ} \mathrm{C}$ for varying times (5-20 minutes). After the preincubation, the substrate (imipramine, $10 \mu \mathrm{M}$ )-stimulated rate of NADPH oxidation was measured as described in Methods. Values are average of duplicate measurements.

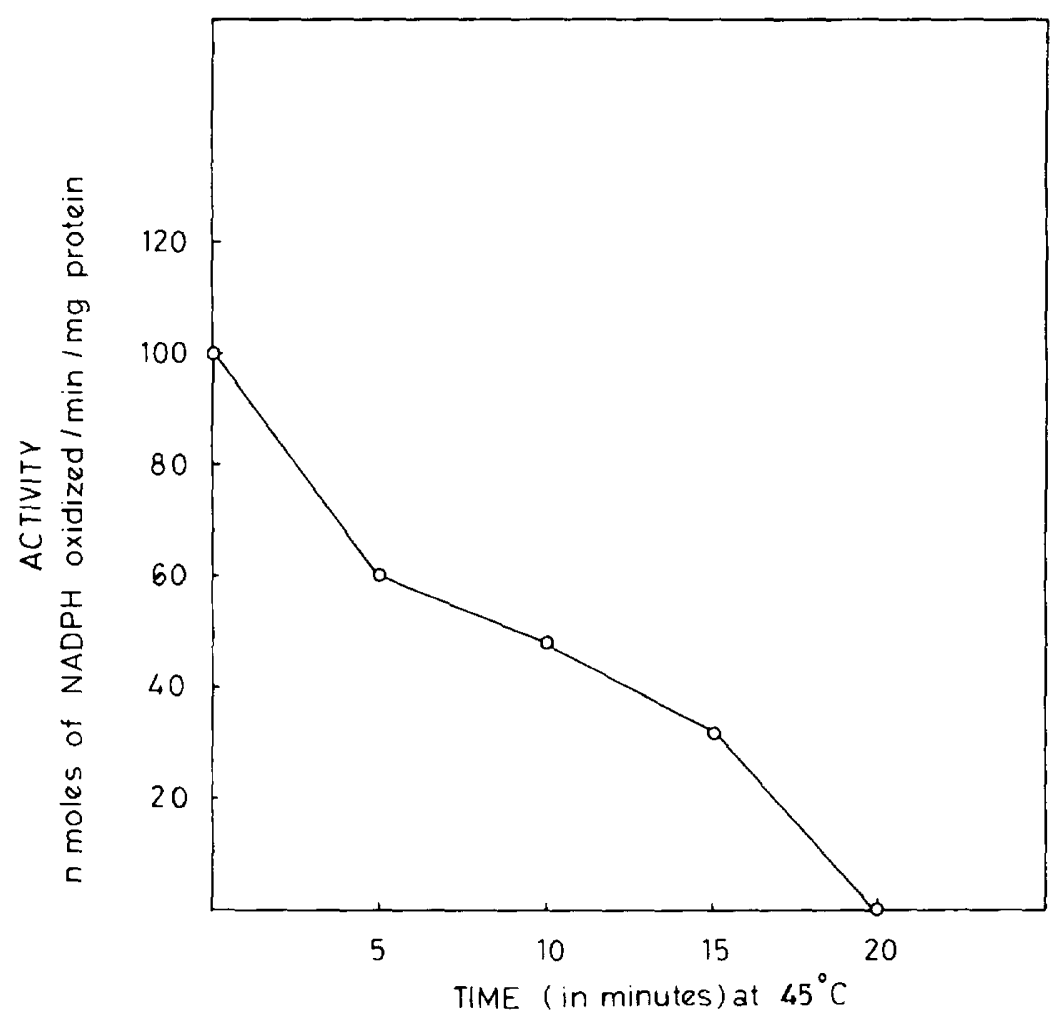

taken into account while calculating the substrate-stimulated rates of NADPH oxidation, the FMO activity is often overestimated when measured in this manner. Hence, in the present study, the FMO activity in human brain has been measured by determining the actual metabolite formation using imipramine as substrate. The FMO activity determined in this manner was typically $56 \%$ to $69 \%$ of the substrate-stimulated rates of NADPH oxidation (Figures 2-3, Table 1). However, in general, the comparative effects of detergents and competitive substrates on the enzyme were reflected in the FMO activity measured as NADPH oxidation rates. Thus, the measurement of FMO activity in this manner may be useful for routine assay, such as during purification, where rapid determination of the enzyme activity is

Table 3. Specific Activity and Fold Purification of Flavin-Containing Monooxygenase Purified from Human Brain Microsomes

\begin{tabular}{lccccc}
\hline & $\begin{array}{c}\text { Protein } \\
\text { (mg) }\end{array}$ & $\begin{array}{c}\text { Specific } \\
\text { Activity }\end{array}$ & $\begin{array}{c}\text { Total } \\
\text { Activity }\end{array}$ & $\begin{array}{c}\text { Yield } \\
\text { (\% Recovery) }\end{array}$ & $\begin{array}{c}\text { Purification } \\
\text { (Fold) }\end{array}$ \\
\hline 1. Microsomes & 326 & 118 & 38,468 & 100 & 1.0 \\
2. Solubilized microsomes & 81 & 343 & 27,783 & 72 & 2.9 \\
3. w-Octylamino-sepharose 4B & 1.54 & 964 & 1,485 & 4.2 & 8.2 \\
4. 2',5'-ADP agarose & 0.13 & 1,125 & 146 & 0.4 & 9.5 \\
5. DEAE-Sephacel & 0.01 & 1,769 & 17.7 & 0.05 & 15.0 \\
\hline
\end{tabular}

The specific activity of the enzyme was assayed using imipramine as substrate and is expressed as nmoles of NADPH oxidized $/ \mathrm{min} / \mathrm{mg}$ protein. All analyses were carried out in duplicate. 


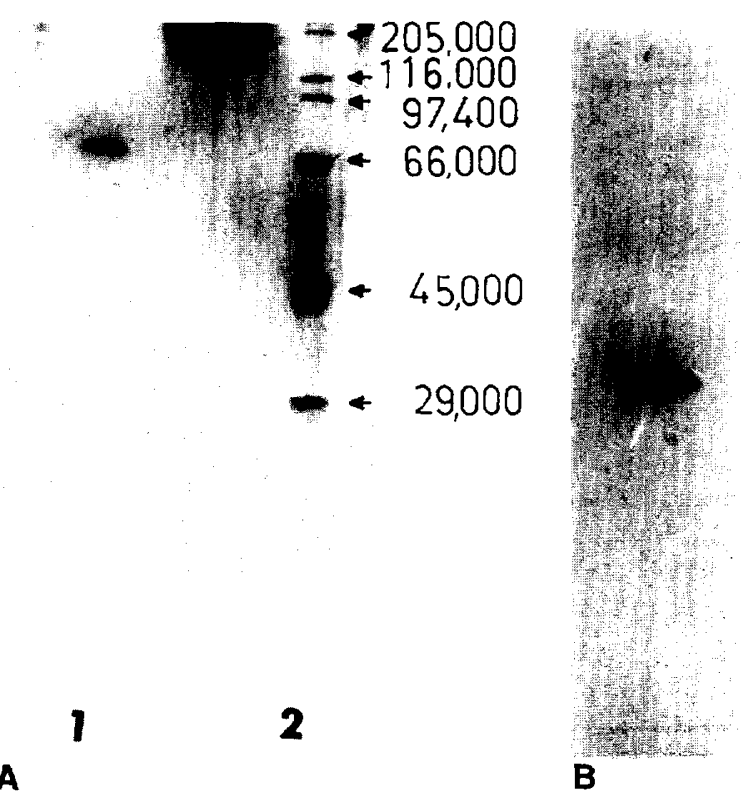

Figure 6. SDS-PAGE and immunoblot of purified human brain FMO. (A) SDS-PAGE of purified human brain FMO. The amount of protein loaded on the gel was $2 \mu \mathrm{g}$ (lane 1). The standard molecular weight markers (lane 2) include myosin $(205,000 \mathrm{Da}), \beta$-galactosidase $(116,000 \mathrm{Da})$, phosphorylase $b(97,400 \mathrm{Da})$, bovine serum albumin $(66,000 \mathrm{Da})$, ovalbumin $(45,000 \mathrm{Da})$, and carbonic anhydrase $(29,000 \mathrm{Da})$. (B) Immunoblot of purified human brain FMO stained with antibody to purified rabbit lung FMO. The amount of protein loaded on the gel was $3 \mu \mathrm{g}$.

necessary. However, the actual product formation needs to be measured in order to assess the enzyme activity accurately.

Interestingly, FMO activity was not measurable in freshly thawed human brain microsomes in the absence of detergents (Figure 1, Table 1). However, in the presence of detergents, significant amounts of metabolite were detectable. The FMO activity (in the absence of detergents) gradually increased as the microsomes were freeze-thawed. Thus, the activity in microsomes that were freeze-thawed five times was 42.6 and increased to 64.3 nmoles of imipramine $\mathrm{N}$-oxide formed $/ \mathrm{min} / \mathrm{mg}$ protein in microsomes that were freeze-thawed eight times. The anionic detergent sodium cholate was a positive modulator of FMO activity, and maximal activity was detectable in the presence of sodium cholate $(0.6 \%$, $\mathrm{w} / \mathrm{v}$ ), regardless of the method of estimation of $\mathrm{FMO}$ activity. Such detergent effects have been observed with rabbit pulmonary FMO and rodent hepatic and pulmonary FMO (Tynes and Hogdson 1985), although the addition of sodium cholate results in loss of pig hepatic FMO activity (Williams et al. 1985). The effects of freeze-thawing of microsomal protein and the addition of detergents possibly improve the accessibility of the substrate to the membrane-bound FMO.

The $\mathrm{pH}$ optimum for the human brain FMO-medi- ated $\mathrm{N}$-oxidation of imipramine was 8.5 , which is more acidic than the $\mathrm{pH}$ optimum for the hepatic FMO $(\mathrm{pH}$ 10). FMO activity was hence assayed in buffers adjusted to $\mathrm{pH}$ 8.5. The human brain FMO was also quite unlike the hepatic FMO as revealed by the thermolability experiments. The pig hepatic FMO is extremely sensitive to increase in temperature (loss of activity after exposure to $45^{\circ} \mathrm{C}$ for 2 minutes), but half the activity was still measurable after exposing the human brain microsomes to $45^{\circ} \mathrm{C}$ for 10 minutes.

The human brain FMO has been shown to share immunological similarity with the rabbit pulmonary FMO (Bhamre et al. 1995). In the present study, immunoinhibition experiments were carried out with this antibody. Preincubation of microsomes with the antibody to the rabbit pulmonary FMO inhibited the human brain FMO-mediated oxidation of imipramine almost completely $(93 \%)$ when the activity was measured as the amount of metabolite formed using HPLC. However, the activity was inhibited by only $32 \%$ when it was measured as the NADPH oxidation rates. The antibody to rabbit pulmonary FMO failed to inhibit the FMO-mediated metabolism of model substrates such as methimazole and $\mathrm{N}^{\prime}, \mathrm{N}^{\prime}$ dimethylaniline and other psychoactive drugs, such as fluoxetine and chlorpromazine (Bhamre et al. 1993b). Thus, the immunoinhibition of FMO activity by this antibody was restricted to the metabolism of imipramine to its N-oxide among the substrates examined. The addition of methimazole as an alternate substrate of FMO resulted in the loss of FMOmediated formation of imipramine $\mathrm{N}$-oxide. Further, the preincubation with the antiserum to rat liver NADPH cytochrome P-450 reductase had no effect on the FMO activity in brain microsomes. These results taken together provide definitive evidence that the metabolism of imipramine to its $\mathrm{N}$-oxide is indeed mediated by human brain FMO.

Finally, a FMO was purified to apparent homogeneity from a human brain cortex. The protein moved as a single band on SDS-PAGE. Immunoblot experiments revealed its immunological similarity to rabbit pulmonary FMO. The purified enzyme efficiently catalyzed the metabolism of the antidepressant, imipramine to its $\mathrm{N}$-oxide as determined by NADPH oxidation and confirmed by HPLC analysis of the metabolite (data not shown). However, the specific activity of the purified FMO was 1,769 nmoles of NADPH oxidized $/ \mathrm{min} / \mathrm{mg}$ protein, indicating 15 -fold purification of the microsomal enzyme. We made similar observations in our efforts to purify the rat brain FMO (Bhagwat et al. 1995). The rat brain FMO was purified 181-fold when the activity was measured using methimazole as substrate. However, the same protein appeared to be purified only 16-fold using imipramine as substrate. These observations indicate the possibility that more than one form of FMO could have contributed to the metabolism of imi- 
pramine by brain microsomes. Unfortunately, we were unable to monitor the FMO activity using methimazole also as a substrate during the purification of human brain FMO because of the small size of the sample, especially during the final stages of purification. Currently, we are attempting to purify human brain FMO in larger quantities to carry out more detailed characterization of the enzyme.

The present study conclusively demonstrates the presence of competent FMO system in the human brain and points to its potential role in the local pharmacological modulation of pharmacological activity and/or toxicity of psychotropic drugs and possible other foreign compounds that are subject to FMO-mediated oxidative metabolism.

\section{ACKNOWLEDGEMENTS}

We are thankful Dr. S. K. Shankar, Department of Neuropathology, NIMHANS, Bangalore, for providing the human autopsy tissues. The authors also thank Dr. D. E. Williams for providing the antibody to rabbit pulmonary FMO and Dr. Ziegler for the standard imipramine N-oxide. We thank Sun Pharmaceutical Industries, India, for the gift of imipramine. SVB thanks CSIR, India, for the award of senior research fellowship. This work was supported through the US-India fund for Cultural, Educational, and Scientific Cooperation.

\section{REFERENCES}

Bhagwat SV, Bhamre S, Boyd MR, Ravindranath V (1996): Characterization of rat brain flavin-containing monooxygenase: Metabolism of imipramine to its N-oxide. Biochem Pharmacol (In Press)

Bhamre S, Ravindranath V (1991): Presence of flavin-containing monooxygenase in rat brain. Biochem Pharmacol 42:442-444

Bhamre S, Shankar SK, Bhagwat SV, Ravindranath V (1993a): Catalytic activity and immunohistochemical localization of flavin-containing monooxygenase in rat kidney. Life Sci 52:1601-1607

Bhamre S, Bhagwat SV, Shankar SK, Williams DE, Ravindranath V (1993b): Cerebral flavin-containing monooxygenase-mediated metabolism of antidepressants in brain: Immunochemical properties and immunohistochemical localization. J Pharmacol Exp Ther 267:555-559

Bhamre S, Bhagwat SV, Shankar SK, Boyd MR, Ravindranath $\mathrm{V}$ (1995): Flavin-containing monooxygenase-mediated metabolism of psychoactive drugs by human brain microsomes. Brain Res 672:276-280

Bradford M (1976): A rapid and sensitive method for the quantitation of microgram quantities of protein utilizing the principle of protein dye-binding. Anal Biochem 72:248-254

Dolphin C, Shephard EA, Povey S, Palmer CN, Ziegler DM, Ayesh R, Smith RL, Phillips IR (1991): Cloning, primary sequence and chromosomal mapping of a human flavin-containing monooxygenase (FMO1). J Biol Chem 266:12379-12385

Gold MS, Ziegler DM (1973): Dimethylaniline N-oxidase and aminopyrine $\mathrm{N}$-demethylase activities of human liver tissues. Xenobiotica 3:179-189

Laemmli UK (1970): Maturation of the head of bacteriophage T4, I. DNA packaging events. Nature 227:680-685

Lemoine A, Johann M, Cresteil T (1990): Evidence of presence of distinct flavin-containing monooxygenase in human tissues. Arch Biochem Biophys 276:336-342

Lomri N, Gu Q, Cashman JR (1992): Molecular cloning of the flavin-containing monooxygenases (form II) cDNA from adult human liver. Proc Natl Acad Sci USA 89:1685-1689

Lowry OH, Rosenburg NJ, Farr AL, Randall RJ (1951): Protein measurement with the Folin phenol reagent. J Biol Chem 193:265-275

Merril CR, Goldman D, Sedman SA, Ebert MH (1981): Ultrasensitive stain for proteins in polyacrylamide gels showing regional variation in cerebrospinal fluid proteins. Science 211:1437-1438

Poulsen LL, Hyslop RM, Ziegler DM (1974): S-Oxidation of thioureylenes catalyzed by a microsomal flavoprotein mixed function oxidase. Biochem Pharmacol 23:34313440

Ravindranath V, Anandatheerthavarada HK (1990): Preparation of brain microsomes with cytochrome P-450 activity using calcium aggregation method. Anal Biochem $187: 310-313$

Ravindranath V, Anandatheerthavarada HK, Shankar SK (1990): NADPH cytochrome P-450 reductase in rat, mouse and human brain. Biochem Pharmacol 39:1013-1018

Towbin H, Staehelin T, Gordon J (1979): Electrophoretic transfer of proteins from polyacrylamide gels to nitrocellulose sheets: Procedure and some applications. Proc Natl Acad Sci USA 76:4350-4354

Tynes RE, Hodgson E (1985): Catalytic activity and substrate specificity of the flavin-containing monooxygenase in microsomal systems: Characterization of the hepatic, pulmonary and renal enzymes of the mouse, rabbit and rat. Arch Biochem Biophys 240:77-93

Tynes RE, Philpot RM (1987): Tissue and species dependent expression of multiple forms of mammalian flavin-containing monooxygenase. Mol Pharmacol 31:569-574

Williams DE, Halle SE, Muerhoff AS, Masters BSS (1985): Rabbit lung flavin-containing monooxygenase: Purification, characterization and induction during pregnancy. Mol Pharmacol 28:381-391

Ziegler DM (1993): Recent studies on the structure and function of multisubstrate flavin-containing monooxygenases. Ann Rev Pharmacol Toxicol 33:179-199

Ziegler DM, Poulsen LL (1978): Hepatic microsomal mixed function oxidase. Meth Enzymol 52:142-151 